\title{
Article \\ Phytochemicals in Chinese Chive (Allium tuberosum) Induce the Skeletal Muscle Cell Proliferation via PI3K/Akt/mTOR and Smad Pathways in C2C12 Cells
}

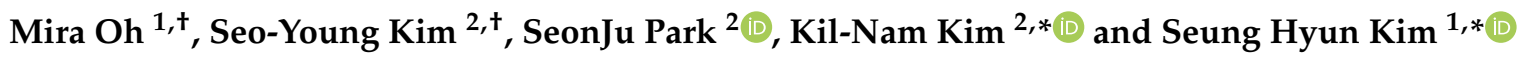 \\ 1 College of pharmacy, Yonsei Institute of Pharmaceutical Sciences, Yonsei University, Incheon 21983, Korea; \\ purunmei2002@naver.com \\ 2 Chuncheon Center, Korea Basic Science Institute (KBSI), Chuncheon 24341, Korea; \\ kimsy11@kbsi.re.kr (S.-Y.K.); sjp19@kbsi.re.kr (S.P.) \\ * Correspondence: knkim@kbsi.re.kr (K.-N.K.); kimsh11@yonsei.ac.kr (S.H.K.); Tel.: +82-33-815-4607 (K.-N.K.); \\ +82-32-749-4514 (S.H.K.); Fax: +82-33-255-7273 (K.-N.K.); +82-32-749-4105 (S.H.K.) \\ + These authors contributed equally to this work.
}

check for updates

Citation: Oh, M.; Kim, S.-Y.; Park, S.; Kim, K.-N.; Kim, S.H. Phytochemicals in Chinese Chive (Allium tuberosum) Induce the Skeletal Muscle Cell Proliferation via PI3K/Akt/mTOR and Smad Pathways in C2C12 Cells. Int. J. Mol. Sci. 2021, 22, 2296. https://doi.org/10.3390/ ijms22052296

Academic Editor: Vivek K. Bajpai

Received: 26 January 2021

Accepted: 22 February 2021

Published: 25 February 2021

Publisher's Note: MDPI stays neutral with regard to jurisdictional claims in published maps and institutional affiliations.

Copyright: (c) 2021 by the authors. Licensee MDPI, Basel, Switzerland. This article is an open access article distributed under the terms and conditions of the Creative Commons Attribution (CC BY) license (https:/ / creativecommons.org/licenses/by/ $4.0 /)$.

\begin{abstract}
Chinese chive (Allium tuberosum) is a medicinal food that is cultivated and consumed mainly in Asian countries. Its various phytochemicals and physiological effects have been reported, but only a few phytochemicals are available for skeletal muscle cell proliferation. Herein, we isolated a new compound, kaempferol-3-O-(6"-feruloyl)-sophoroside (1), along with one known flavonoid glycoside (2) and six amino acid (3-8) compounds from the water-soluble fraction of the shoot of the Chinese chive. The isolated compounds were identified using extensive spectroscopic methods, including 1D and 2D NMR, and evaluated for their proliferation activity on skeletal muscle cells. Among the tested compounds, newly isolated flavonoid (1) and 5-aminouridine (7) up-regulated PI3K/Akt/mTOR pathways, which implies a positive effect on skeletal muscle growth and differentiation. In particular, compound 1 down-regulated the Smad pathways, which are negative regulators of skeletal muscle growth. Collectively, we suggest that major constituents of Chinese chive, flavonoids and amino acids, might be used in dietary supplements that aid skeletal muscle growth.
\end{abstract}

Keywords: Allium tuberosum; Chinese chive; cell proliferation; flavonoid glycoside; skeletal muscle differentiation

\section{Introduction}

There is an age-related loss in skeletal muscle mass and strength, known as sarcopenia [1]. Sarcopenia poses a huge health care burden in the elderly [2]. Therefore, many researchers are interested in finding dietary ingredients from natural products that can help increase and maintain skeletal muscle mass.

Chinese chive (Allium tuberosum, Liliaceae) is a hardy perennial plant, which has edible thin leaves. It is mainly cultivated and consumed in east and southeast Asia not only as food but also as medicine. According to the dictionary of Chinese drugs [3], Chinese chive has been used for the treatment of abdominal pain, diarrhea, hematemesis, snakebite, and asthma. Indeed, several studies of Chinese chive's biological and physiological activities support its wide range of medicinal effects; Tang et al. (2017) [4] confirmed the antidiabetic and hepatoprotective effect of Chinese chive extract's butanol fraction, and they expected that it might be due to the influence of protective effect against liver injury. Chinese chive also showed significant hypolipidemic activity in hyperlipidemic guineapigs by reducing serum cholesterol, triglyceride, LDL-C, and atherogenic index [5]. The report about cytotoxic activity indicated that thiosulfinates from Chinese chive inhibited cell proliferation in HepG2 via apoptosis [6]. Despite these diverse physiological activities, there are no reports about skeletal muscle cell proliferation activity of Chinese chive. 
However, muscle-related reports have been published using Allium genus. For instance, Gautam et al. (2015) [7] confirmed that onion (A. cepa) stimulates glucose uptake, which is related to skeletal muscle growth and mass increase in L6 rat skeletal muscle cells [8]. In addition, macrostemonoside A, a new compound isolated from A. macrostemon Bung, promoted energy metabolism in muscles during its action mechanisms on mice [9]. More recently, Kalhotra et al. (2020) [10] reported that garlic bulb (A. sativum) extract on L6 cells increased cell proliferation and/or differentiated skeletal muscle cells compared to untreated cells.

In this study, we isolated and identified phytochemicals from the methanol extracts of Chinese chive to find a substance that has a positive effect on muscle growth. Using various chromatographic techniques and extensive spectroscopic methods, eight compounds were identified. Among tested compounds, a new flavonol glycoside and an amino acid exhibited significant skeletal muscle cell proliferation.

\section{Results and Discussion}

\subsection{Chemical Composition of Chinese Chive}

LC-MS total ion current (TIC) chromatograms were acquired from the Chinese chive's shoots sample for spectrometric analysis of compound composition. Methanol extract of the sample was strongly ionized in the ESI-negative mode (Figure 1).

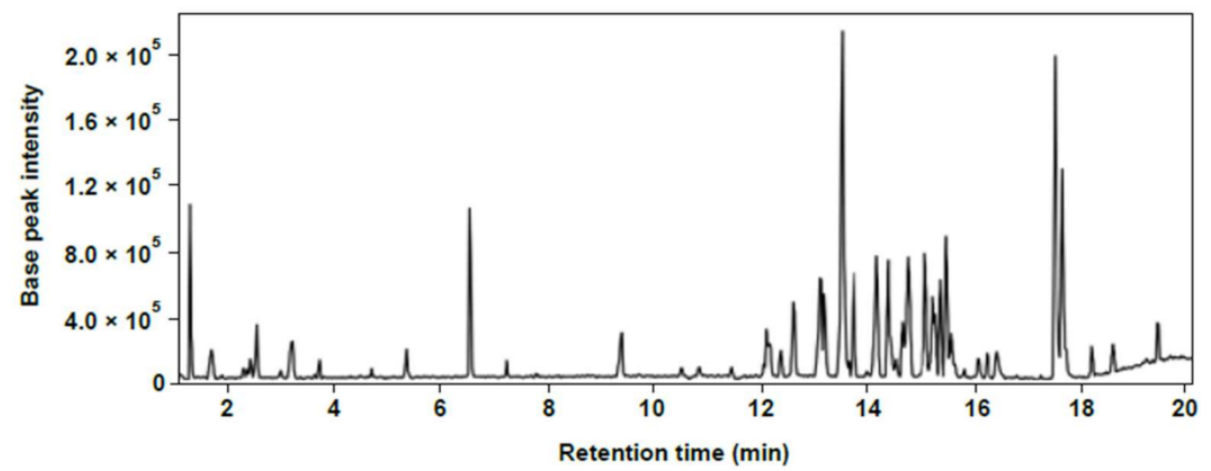

Figure 1. Representative LC-MS total ion current (TIC) chromatograms of methanol extract of Chinese chive in negative ion mode.

In order to identify the various compounds of Chinese chive, molecular networking was performed. Recently, network annotation propagation (NAP) was introduced as an in silico annotation tool, which predicts the compound structure of unknown fragmented mass spectrum with a re-ranking system to increase annotation accuracy [11]. Molecular networking of Chinese chive was generated using the raw negative ion mode LC-MS data and visualized through Cytoscape 3.8.0, an open-source software for visualizing complex networks [12] (Figure S1). Of the 102 nodes, the structures of 71 nodes were predicted in silico. The molecular networking work on NAP can be found at Center for Computational Mass Spectrometry. Available online: https:/ / proteomics2.ucsd.edu/ProteoSAFe/status. jsp?task=3f047829fb864932b2e4e49c656b1920 (accessed on 20 December 2020).

Chemical classification of 66 nodes, of 71 nodes annotated with NAP, was yielded through ClassyFire program [13]. The "phenylpropanoids and polyketides" group showed the largest proportion (22.7\%) among the seven superclass levels, followed by "lipid and lipid-like molecules" (21.2\%) and "organoheterocyclic compounds" (18.2\%). The largest chemical constituents that included in the "phenylpropanoids and polyketides" group were "flavonoids" (Figure 2). Of the 26 class levels detected in Chinese chive, the following seven classes constituted the top $54.5 \%$; "steroids and steroid derivatives", "lupin alkaloids", "benzene and substituted derivatives", "carboxylic acids and derivatives", "glycerophospholipids", "flavonoids", and "piperidines". The subclass levels constituting each of the seven classes are shown in Figure 3. 


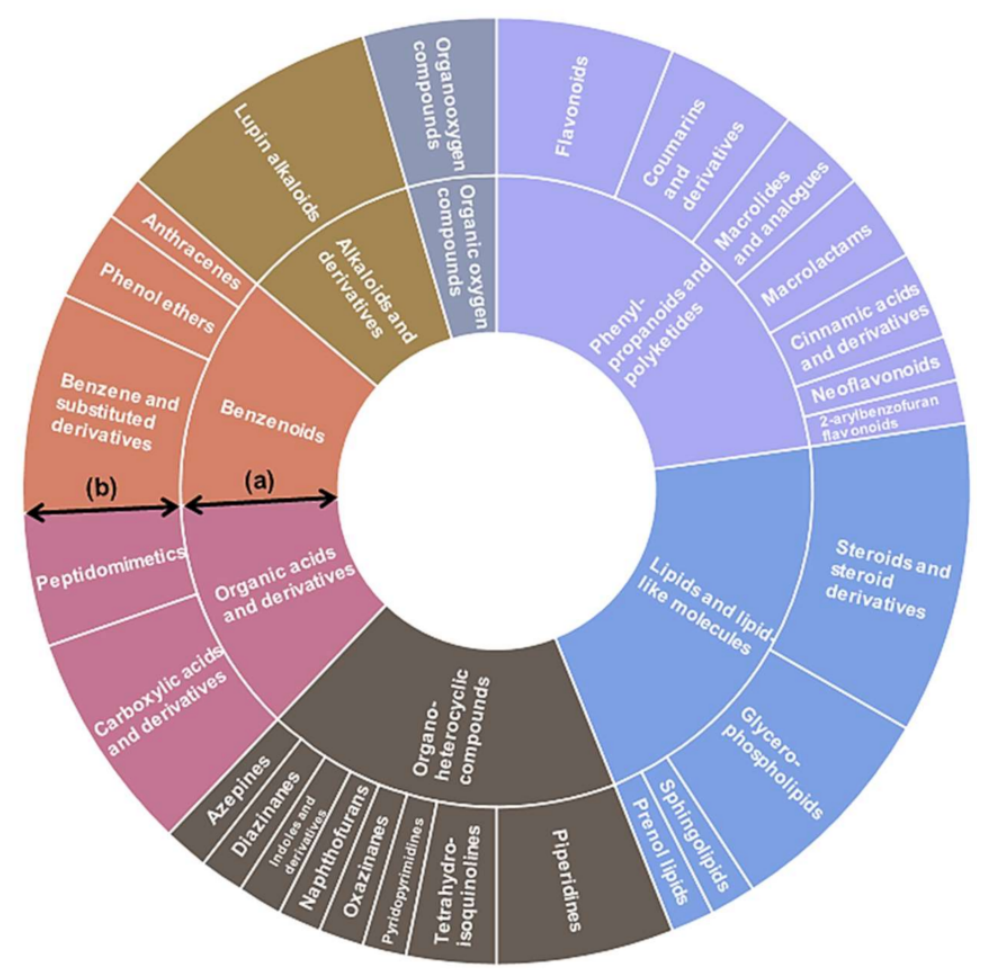

Figure 2. Sunburst plot of organic compounds annotated in Chinese chives. Nodes annotated by NAP were classified as different class levels using ClassyFire. (a) superclass level; (b) class level.

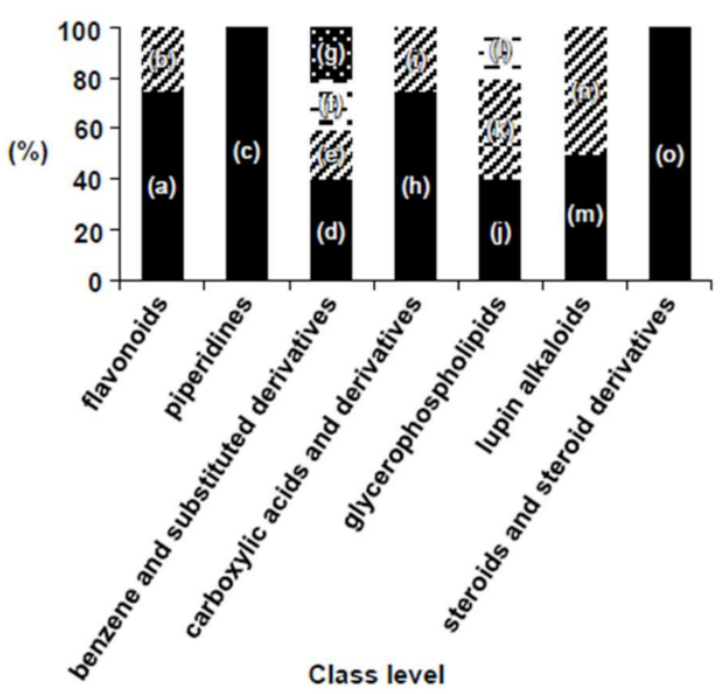

Figure 3. Bar plot of organic compounds annotated in Chinese chives. Each bars of seven class levels consist of one or more subclass levels. (a) flavonoid glycosides; (b) flavans; (c) phenylpiperidines; (d) benzyl alcohols; (e) benzoic acids and derivatives; (f) diphenylmethanes; (g) sulfanilides; (h) amino acids and derivatives; (i) peptides; (j) glycerophosphocholines; (k) glycerophosphoethanolamines; (l) glycerophosphoinositols; (m) cytisine and derivatives; (n) matrine alkaloids; (o) ergosterols and derivatives.

\subsection{Isolation and Identification of Phytochemicals in Chinese Chive Extract}

The methanol extract of the shoots of Chinese chive was suspended in water and partitioned using $\mathrm{CHCl}_{3}$ and $\mathrm{EtOAc}$ to obtain three layers. By means of various chromatographic and isolation approaches, one new compound along with eight known compounds were isolated (Figure 4). The known compounds were compared with the reported ${ }^{1} \mathrm{H},{ }^{13} \mathrm{C}$ NMR, and MS data and were identified as kaempferol-3-O-sophoroside (2) [14], thymidine 
(3) [15], 2'-deoxyadenosine and adenosine $(4,5)$ [16], uridine (6) [17], 5-aminouridine (7), and tryptophan (8) [18].

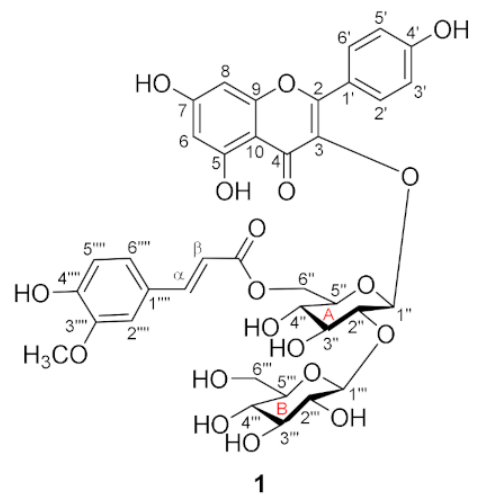

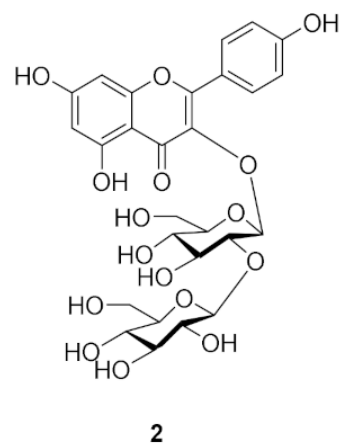<smiles>Cc1cn(C2CC(O)C(CO)O2)c(=O)[nH]c1=O</smiles><smiles>NC1NC=Nc2c1ncn2C1OC(CO)C(O)C1O</smiles><smiles>O=c1ccn(C2OC(CO)C(O)C2O)c(=O)[nH]1</smiles>

6<smiles>Nc1cn(C2OC(CO)C(O)C2O)c(=O)[nH]c1=O</smiles><smiles>NC(Cc1c[nH]c2ccccc12)C(=O)O</smiles>

8

Figure 4. Chemical structures of compounds 1-8. 1, kaempferol-3-O-(6 $6^{\prime \prime}$-feruloyl)-sophoroside; 2, kaempferol-3-O-sophoroside; 3, thymidine; 4, 2'-deoxyadenosine; 5, adenosine; 6, uridine; 7 , 5-aminouridine; 8, tryptophan.

Compound 1 was obtained as a yellow amorphous powder, and its molecular formula was determined as $\mathrm{C}_{37} \mathrm{H}_{38} \mathrm{O}_{19}$ by HR-ESI-MS ion at $m / z 809.1889[\mathrm{M}+\mathrm{Na}]^{+}$(calcd for $\mathrm{C}_{37} \mathrm{H}_{38} \mathrm{O}_{19}$, 809.1900) (Figure S2). The ${ }^{1} \mathrm{H}-\mathrm{NMR}$ spectrum exhibited the existence of kaempferol backbone: $\mathrm{A}_{2} \mathrm{~B}_{2}$-type benzene ring at $\delta_{\mathrm{H}} 6.90(2 \mathrm{H}, \mathrm{d}, J=8.6 \mathrm{~Hz})$ and $8.06(2 \mathrm{H}$, $\mathrm{d}, J=8.6 \mathrm{~Hz})$ and two methine signals at $\delta_{\mathrm{H}} 6.12(\mathrm{~d}, J=2.1 \mathrm{~Hz})$ and $6.18(\mathrm{~d}, J=2.1 \mathrm{~Hz})$. In addition, ${ }^{1} \mathrm{H}-\mathrm{NMR}$ spectrum exhibited the signals of feruloyl moiety: two olefinic methine signals at $\delta_{\mathrm{H}} 6.05(\mathrm{~d}, J=15.9 \mathrm{~Hz})$ and $7.34(\mathrm{~d}, J=15.9 \mathrm{~Hz})$ and ABC-type benzene ring at $\delta_{\mathrm{H}} 6.65(\mathrm{~d}, J=8.1 \mathrm{~Hz}), 6.72(\mathrm{dd}, J=1.9,8.2 \mathrm{~Hz})$, and $6.82(\mathrm{~d}, J=1.9 \mathrm{~Hz})$, as well as methoxy proton at $\delta_{\mathrm{H}} 3.79$ (s). The ${ }^{13} \mathrm{C}$ NMR spectrum of 1 showed the presence of a total of 37 carbons, 13 quaternary carbons ( 1 carboxyl, 1 carbonyl, 8 oxygenated), 21 methines (ten oxygenated), 2 oxygenated methylenes, and 1 methoxy carbon (Table 1). The NMR data of $\mathbf{1}$ were similar to those of kaempferol 3-O-[2-O-( $\beta$-glucopyranosyl)-6$O$-(trans-sinapoyl)- $\beta$-glucopyranoside] [19] except for the replacement of sinapoyl into feruloyl moiety. While the sinapoyl moiety normally exhibits $\mathrm{A}_{2}$-type benzene ring with two methoxy groups, the NMR spectrum of compound 1 showed the ${ }^{1} \mathrm{H}-\mathrm{NMR}$ signals of ABC-type benzene ring containing one methoxy group, which was assigned as a feruloyl moiety. Two olefinic protons at $\mathrm{H}-\alpha\left(\delta_{\mathrm{H}} 7.34\right)$ and $\mathrm{H}-\beta\left(\delta_{\mathrm{H}} 6.05\right)$ of the feruloyl moiety with large coupling constants $(J=15.9 \mathrm{~Hz})$ indicated that the geometry of the olefin was trans-configuration. Both sugar moieties were identified as $\beta$-D-glucopyranoside (glucoses $\mathrm{A}$ and $\mathrm{B})$ by comparing with the sugar moieties in quercetin-3-O-(6"-feruloyl)-sophoroside (Table 1) [20] and acid hydrolysis of $\mathbf{1}$ (see experimental). The HMBC correlation between the methoxy proton $\left(\delta_{\mathrm{H}} 3.79\right)$ and the carbon signals at $\mathrm{C}-3^{\prime \prime \prime \prime}\left(\delta_{\mathrm{C}} 149.2\right)$ confirmed the 
location of the methoxy at C-3'"' (Figure 5). The location of sugar moieties at C-3 was assigned by the HMBC correlation from $\mathrm{H}-1^{\prime \prime}\left(\delta_{\mathrm{H}} 5.12\right)$ to $\mathrm{C}-3\left(\delta_{\mathrm{C}} 135.3\right)$, while the location of glucose B was designated at C-2" by the HMBC correlation between $\mathrm{H}-1^{\prime \prime \prime}\left(\delta_{\mathrm{H}} 4.75\right)$ and $C-2 "\left(\delta_{C} 84.7\right)$. Furthermore, the position of feruloyl moiety at C- 6 " was confirmed by the HMBC correlation between the H-6" $\left(\delta_{\mathrm{H}} 4.44\right.$ and 4.45$)$ and C- 6 " $\left(\delta_{\mathrm{C}} 169.0\right)$ (Figure 5). Based on the above data, the structure of compound $\mathbf{1}$ was determined as kaempferol-3-O(6"-feruloyl)-sophoroside. Raw 1D and 2D NMR spectrum data are shown in supporting information (Figure S3-S6).

Table 1. NMR spectroscopic data for compound 1.

\begin{tabular}{|c|c|c|c|c|c|}
\hline Pos. & $\delta_{\mathrm{C}}^{\mathrm{a}, \mathrm{b}}$ & $\delta_{\mathrm{H}^{\mathrm{a}, \mathrm{c}}}(J$ in $\mathrm{Hz})$ & Pos. & $\delta_{\mathrm{C}}^{\mathrm{a}, \mathrm{b}}$ & $\delta_{\mathrm{H}}^{\mathrm{a}, \mathrm{c}}(J$ in $\mathrm{Hz})$ \\
\hline Kaempferol & & & Glucose B & & \\
\hline 2 & 158.5 & & $1^{\prime \prime \prime}$ & 106.2 & $4.75(\mathrm{~d}, 7.5)$ \\
\hline 3 & 135.3 & & $2^{\prime \prime \prime}$ & 75.7 & $3.66^{*}$ \\
\hline 4 & 180.0 & & $3^{\prime \prime \prime}$ & 77.9 & 3.49 * \\
\hline 5 & 163.1 & & $4^{\prime \prime \prime}$ & 72.0 & 3.41 * \\
\hline 6 & 99.9 & $6.12(\mathrm{~d}, 2.1)$ & $5^{\prime \prime \prime}$ & 76.3 & 3.43 * \\
\hline 7 & 165.7 & & $6^{\prime \prime \prime}$ & 62.4 & $3.64 *, 3.51 *$ \\
\hline 8 & 94.8 & $6.18(\mathrm{~d}, 2.1)$ & & & \\
\hline 9 & 158.3 & & & Ferulic acid & \\
\hline \multirow[t]{2}{*}{10} & 105.8 & & $1^{\prime \prime \prime \prime \prime}$ & 127.4 & \\
\hline & & & $2^{\prime \prime \prime \prime \prime}$ & 111.2 & $6.82(\mathrm{~d}, 1.9)$ \\
\hline $1^{\prime}$ & 122.6 & & $3^{\prime \prime \prime \prime}$ & 149.2 & \\
\hline $2^{\prime}$ & 132.8 & $8.06(\mathrm{~m})$ & $4^{\prime \prime \prime \prime \prime}$ & 150.5 & \\
\hline $3^{\prime}$ & 116.4 & $6.90(\mathrm{~m})$ & $5^{\prime \prime \prime \prime}$ & 116.3 & $6.65(\mathrm{~d}, 8.1)$ \\
\hline $4^{\prime}$ & 161.7 & & $6^{\prime \prime \prime \prime}$ & 124.0 & $\begin{array}{c}6.72(\mathrm{dd}, 1.9 \\
8.2)\end{array}$ \\
\hline $5^{\prime}$ & 116.4 & & $\alpha$ & 146.9 & $7.34(\mathrm{~d}, 15.9)$ \\
\hline \multirow[t]{2}{*}{$6^{\prime}$} & 132.8 & - & $\beta$ & 115.0 & $6.05(\mathrm{~d}, 15.9)$ \\
\hline & & & $-\mathrm{COO}$ & 169.0 & \\
\hline Glucose A & & & $-\mathrm{OCH}_{3}$ & 56.3 & $3.79(\mathrm{~s})$ \\
\hline $1^{\prime \prime}$ & 101.3 & $5.12(\mathrm{~d}, 7.5)$ & & & \\
\hline $2^{\prime \prime}$ & 84.7 & $3.71 *$ & & & \\
\hline $3^{\prime \prime}$ & 78.3 & 3.11 * & & & \\
\hline $4^{\prime \prime}$ & 71.0 & $3.39 *$ & & & \\
\hline $5^{\prime \prime}$ & 77.8 & $3.53 *$ & & & \\
\hline $6^{\prime \prime}$ & 64.8 & $4.44^{*}, 4.45^{*}$ & & & \\
\hline
\end{tabular}

$\overline{\mathrm{a}}$ Measured in methanol- $d_{4},{ }^{\mathrm{b}} 100 \mathrm{MHz},{ }^{\mathrm{c}} 400 \mathrm{MHz},{ }^{*}$ overlapped signal, assignments were done by HSQC, HMBC, COSY, and NOESY experiments.

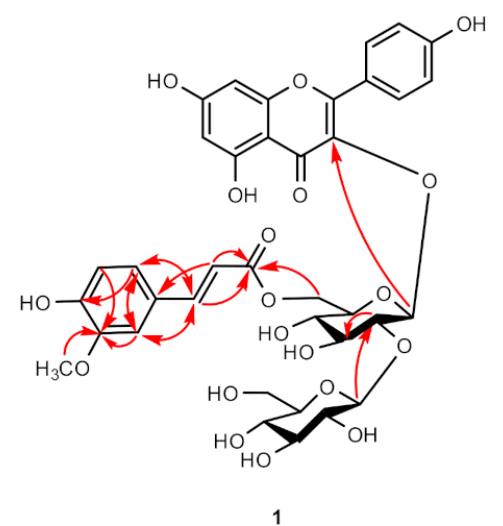

Figure 5. Key HMBC correlations of $\mathbf{1}$. 


\subsection{Skeletal Muscle Cell Proliferation Activities of Phytochemicals from Chinese Chive on C2C12 Cells}

Prior to evaluating the cell proliferation effect of isolated compounds from Chinese chive, their viability on C2C12 myoblasts was measured by 3-(4-5-dimethyl-2yl)-2-5diphynyltetrasolium bromide (MTT) assay. All compounds did not show a cytotoxic effect on $\mathrm{C} 2 \mathrm{C} 12$ cells at the concentration of $50 \mu \mathrm{M}$ except for compound 4 (Figure $6 \mathrm{~A}$ ).

\section{A}

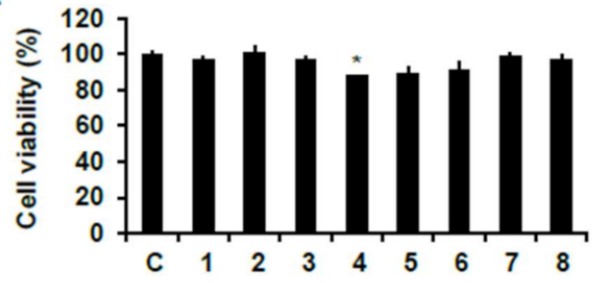

B

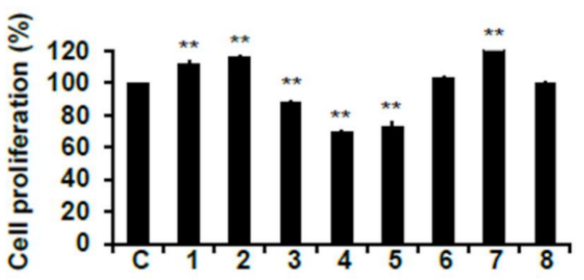

Figure 6. Skeletal muscle cell proliferation activities of phytochemicals from Chinese chive on $\mathrm{C} 2 \mathrm{C} 12$ cells. (A) Cytotoxicity of phytochemicals on C2C12 cells. Cells were incubated for $24 \mathrm{~h}$ after seeding, and then treated phytochemicals for $24 \mathrm{~h}$. After, MTT assay was performed. (B) Cell proliferation activity of phytochemicals on C2C12 cells. Cells were incubated for $48 \mathrm{~h}$ after seeding, and phytochemicals were treated while being replaced with three differentiation medium during six days of the differentiation period. After the differentiation period, cell proliferation activity was measured using BrdU assay. C, control. Experiments were performed in triplicate and the data were expressed as mean $\pm \mathrm{SE}^{*} p<0.01,{ }^{* *} p<0.01$ as compared to the control (untreated cells).

The skeletal muscle cell proliferation of isolated compounds was assessed using 5bromo-2'-deoxyuridine (BrdU) cell proliferation assay. As shown in Figure 6B, compounds $\mathbf{1}, \mathbf{2}$, and 7 significantly increased the proliferation of myoblast compared to the non-treated cells. However, the other five compounds did not exert any effect on cell proliferation. Among them, compounds 3-5 significantly reduced cell proliferation. This result may be caused by cell toxicity due to three treatments of the compounds during the cell differentiation process. Therefore, we selected compound $\mathbf{1}$, which is a newly isolated compound from Chinese chive in the present study, and compound 7, which displayed the highest cell proliferation efficacy among three proliferative compounds, and evaluated the effect of skeletal muscle growth regulation.

\subsection{Effect of Skeletal Muscle Growth Regulation of Compounds $\mathbf{1}$ and $\mathbf{7}$ from Chinese Chive via PI3K/Akt/mTOR and/or Smad Signaling Pathways}

The differentiation and maturation of skeletal muscle require interactions between signaling pathways [21]. For instance, insulin-like growth factor-1 (IGF-1) plays a crucial role in the control of skeletal muscle growth during development [22]. IGF-1 binding to its receptor induces a phosphorylation of phosphoinositide 3 kinase (PI3K)/Akt pathway, resulting in myoblast differentiation and survival [18]. In addition, Akt activates mammalian target of rapamycin (mTOR) and increases protein synthesis via activation of ribosomal protein S6 kinase (S6K) [23]. Therefore, we analyzed the expression of proteins in the signaling pathways discussed below through Western blot analysis to determine whether two active compounds ( $\mathbf{1}$ and $\mathbf{7}$ ) regulate signaling pathways.

As shown in Figure 7B-D, compound $\mathbf{1}$ significantly increased the protein expression levels of $\mathrm{p}$-PI3K, $\mathrm{p}$-Akt, and p-FoxO1 compared to the non-treated cells. Compound 7 
also significantly promoted these protein expression levels comparing the non-treated cells (Figure 8B-D). Then, we analyzed the expression level of mTOR pathways, which are involved in cell proliferation and differentiation by $\mathrm{p}$-Akt. The protein expression level of $\mathrm{p}$-mTOR and p-70S6K were significantly increased by both compounds 1 and 7 compared to the nontreated cells (Figure 7E-F and Figure 8E-F). However, these protein expression levels were more activated in cells with the treatment of compound 7 than that of 1 . Collectively, both compounds induce muscle cell growth through p-mTOR/p70S6K via the p-PI3K/Akt, and compound $\mathbf{7}$ is especially believed to activate this signaling pathway more than compound $\mathbf{1}$ (Figure S7). We moved further to assess the expression level of MyoD, a protein in animals that plays a major role in regulating muscle development and takes part in the repair of damaged skeletal muscle by PI3K/Akt/mTOR signaling pathways [22,24]. As shown in 7G and 8G, the protein expression level of MyoD was significantly increased by both compounds $\mathbf{1}$ and $\mathbf{7}$. The expression level of MyoD protein was also higher in the cells treated with compound 7 than that of $\mathbf{1}$ (Figure S7). In addition, it is believed to be due to the results that the expression level of PI3K/Akt/mTOR was more activated by treating compound 7 than that of compound 1. On the other hand, in cells treated with a high concentration of compound 7 , the expression level of MyoD was not different compared to that of the non-treated cells. Flavonoids and plant extracts containing flavonoid derivatives have been reported to activate osteogenic and myogenic differentiation as well as glucose resistance regulation via PI3K/Akt/mTOR pathways [25-28]. Meanwhile, amino acids are important regulators of the activation of mTOR complex 1, which regulates essential cellular processes such as growth, proliferation, and survival [29]. Furthermore, amino acids regulate cell proliferation by regulating PI3K/Akt signaling and module mTOR complexes [30,31]. In accordance with previous studies, amino acids also positively regulate the PI3K/Akt/mTOR pathways in C2C12 cells. Based on the present studies, we suggest that two active compounds obtained from Chinese chive affect myogenic differentiation via PI3K/Akt/mTOR pathways in C2C12 cells.

A

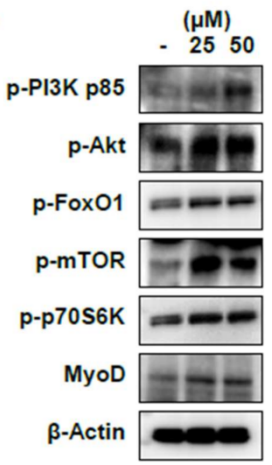

B

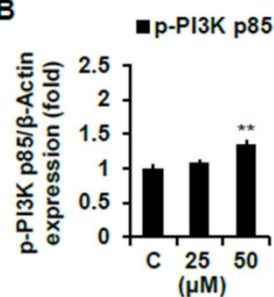

E

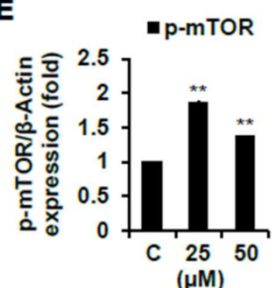

C

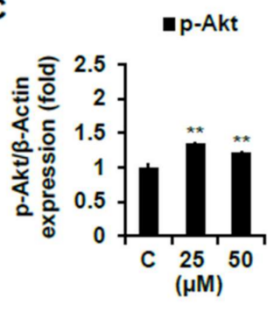

$\mathbf{F}$

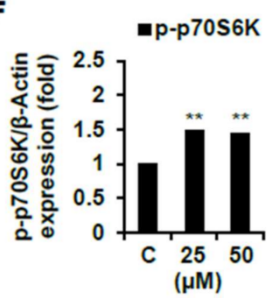

D

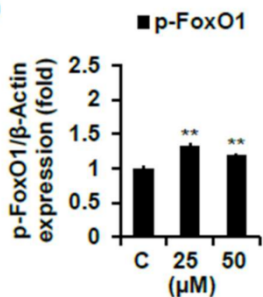

G

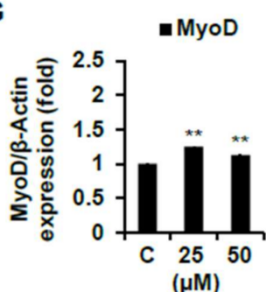

Figure 7. Skeletal muscle cell differentiation activity of compound 1 on $\mathrm{C} 2 \mathrm{C} 12$ differentiated cells. The levels of p-PI3K p85, p-Akt, p-FoxO1, p-mTOR, p-p70S6K, and MyoD proteins were determined using a Western blot analysis. Every level of proteins versus $\beta$-Actin were measured by densitometry. $C$, control. Experiments were performed in triplicate and the data are expressed as mean $\pm \mathrm{SE}$; ** $p<0.01$ as compared to the control (untreated cells). 
A

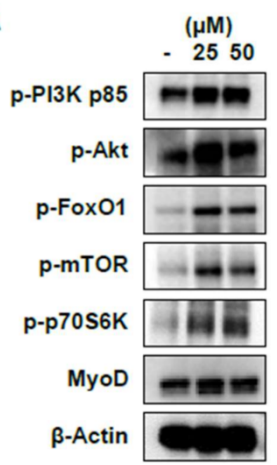

B

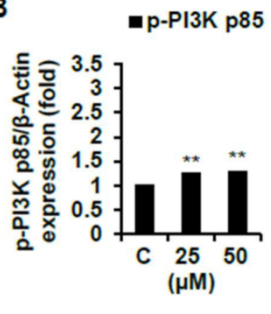

E

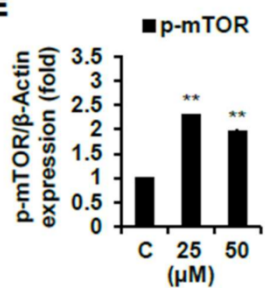

C

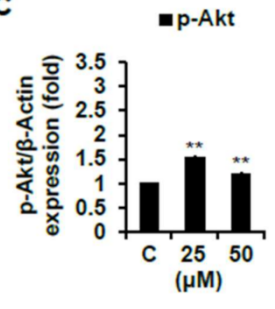

F

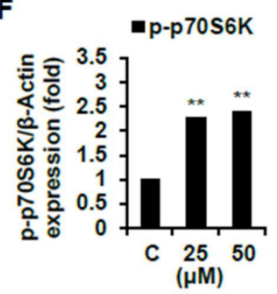

D

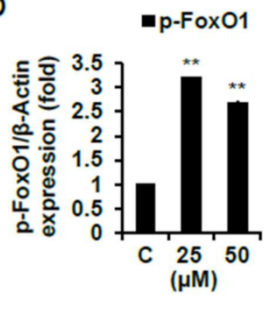

G

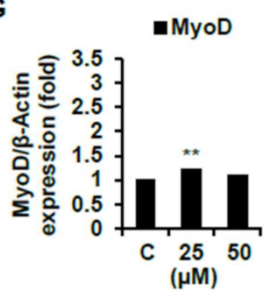

Figure 8. Skeletal muscle cell differentiation activity of compound 7 on $\mathrm{C} 2 \mathrm{C} 12$ differentiated cells. The levels of p-PI3K p85, p-Akt, p-FoxO1, p-mTOR, p-p70S6K, and MyoD proteins were determined using a Western blot analysis. Every level of proteins versus $\beta$-Actin were measured by densitometry. $\mathrm{C}$, control. Experiments were performed in triplicate and the data are expressed as mean $\pm \mathrm{SE}$; ** $p<0.01$ as compared to the control (untreated cells).

The other pathway involved in muscle growth and differentiation is the Smad signaling pathways that are activated in response to TGF- $\beta$. Activated TGF- $\beta$ receptors phosphorylate Smad2/3, and each of the two receptor-activated Smads forms heteromeric complexes with Smad 4 [32]. This complex translocates to the nucleus and down-regulates transcription of target genes such as MyoD. Therefore, we tried to determine whether compounds 1 and 7 down-regulate these Smad pathways. As shown in Figure 9, compound 1 significantly decreased the protein expression levels of $\mathrm{p}-\mathrm{Smad} 2 / 3$ and Smad4 compared to the non-treated cells. Similarly, several studies were reported that flavonoid found in plants down-regulate the Smad signaling pathways [33-35]. However, in compound 7-treated cells, both p-Smad2/3 and Smad4 protein did not decrease but rather increased their expression levels (Figure 10).

A

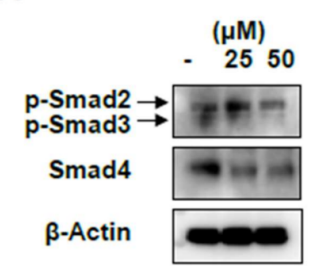

C

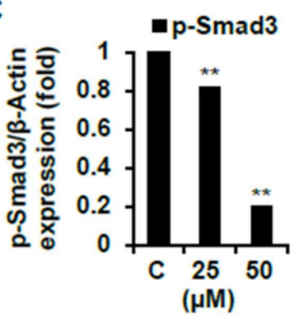

B

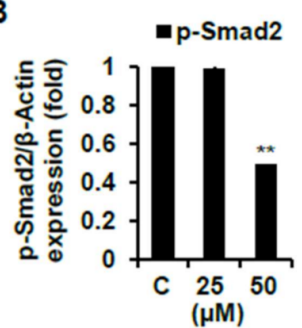

D

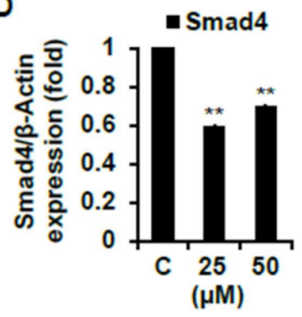

Figure 9. Skeletal muscle cell differentiation activity of compound 1 on C2C12 differentiated cells. The levels of $\mathrm{p}-\mathrm{Smad} 2 / 3$ and Smad 4 proteins were determined using a Western blot analysis. Every level of proteins versus $\beta$-Actin were measured by densitometry. $C$, control. Experiments were performed in triplicate and the data were expressed as mean $\pm \mathrm{SE}$; ${ }^{* *} p<0.01$ as compared to the control (untreated cells). 
A

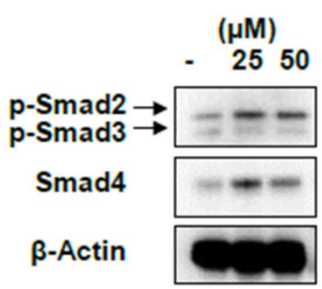

C

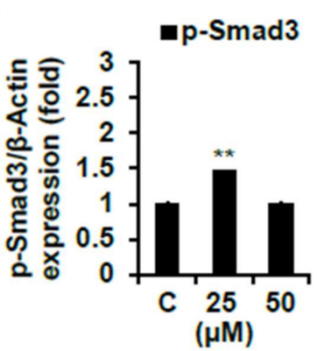

B
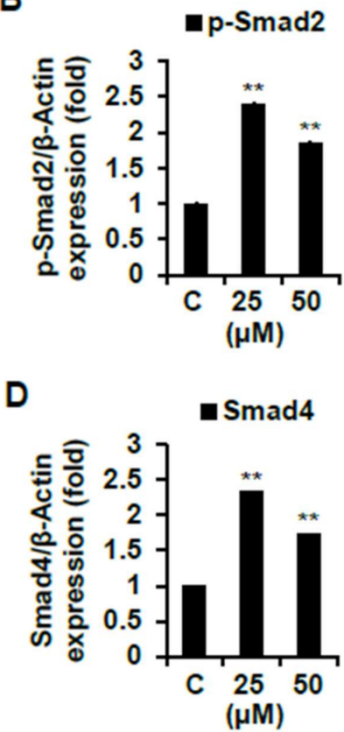

Figure 10. Skeletal muscle cell differentiation activity of compound 7 on C2C12 differentiated cells. The levels of p-Smad2/3 and Smad4 proteins were determined using a Western blot analysis. Every level of proteins versus $\beta$-Actin were measured by densitometry. $C$, control. Experiments were performed in triplicate and the data were expressed as mean $\pm \mathrm{SE}$; ${ }^{* *} p<0.01$ as compared to the control (untreated cells).

Overall, compound 1 not only activated the PI3K/Akt/mTOR signaling pathways but also down-regulated the Smad pathways. On the other hand, compound 7, an amino acid, promoted only the PI3K/Akt/mTOR signaling pathways but could not regulate the Smad pathways. Therefore, it can be deduced that compound 1 exerted more influence on the expression of MyoD, a factor in the nucleus involved in skeletal muscle development, than that of compound 7. Therefore, our results suggest that newly isolated flavonol glycoside and 5-aminouridine have skeletal muscle growth and development effects by promoting the PI3K/Akt/mTOR pathways and down-regulating Smad pathways (Figure 11).

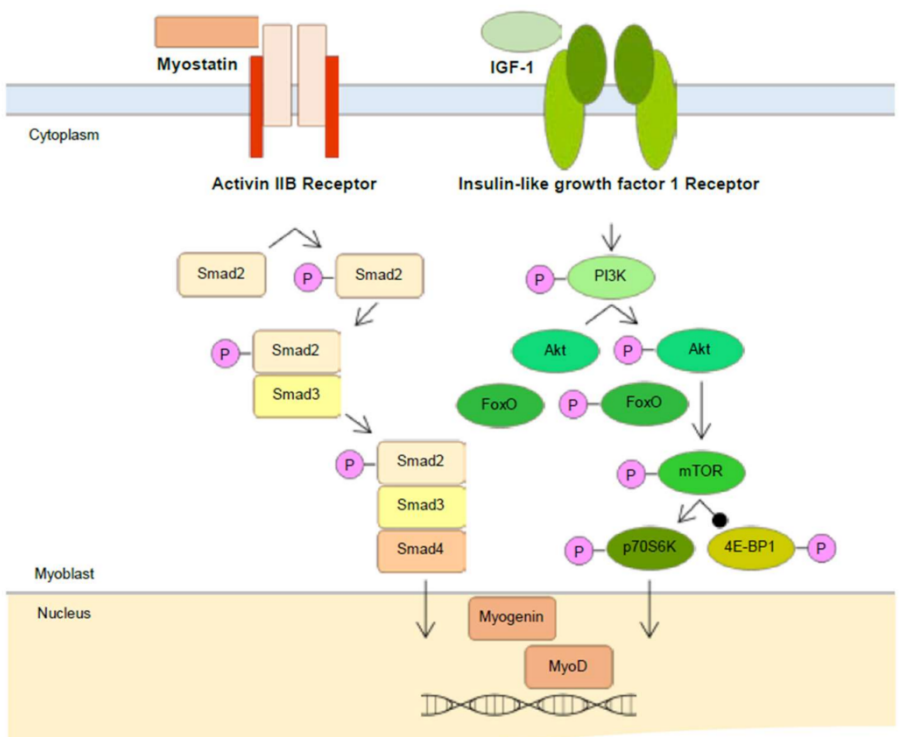

Figure 11. Mechanisms of Myostatin and IGF-1 mediated regulation of skeletal muscle differentiation. 


\section{Materials and Methods}

\subsection{General Experimental Procedures}

Chemical shifts are reported in parts per million from TMS. All NMR spectra were recorded on an Agilent 400-MR-NMR spectrometer operated at 400 and $100 \mathrm{MHz}$ for hydrogen and carbon, respectively. Data processing was carried out with the MestReNova ver.6.0.2 program. The IR spectra were obtained from a Tensor 37 FT-IR spectrometer (Bruker, Ettlingen, Germany). UV and Circular dichroism spectrums were determined on a Chirascan ${ }^{\mathrm{TM}}$ CD spectrometer. Preparative HPLC was carried out using an AGILENT 1200 HPLC system. Column chromatography (CC) was performed on silica-gel (Kieselgel 60, 70230 mesh and 230-400 mesh, Merck, Kenilworth, NJ, USA), YMC RP-18 resins (30-50 $\mu \mathrm{m}$, Fujisilisa Chemical Ltd., Kasugai, Aichi, Japan), or Diaion HP-20 regins (200-300 mesh, Mitsubishi Chemical Co., Chiyoda, Tokyo, Japan). For thin-layer chromatography (TLC), pre-coated silica-gel 60 F254 (0.25 mm, Merck) and RP-18 F254S (0.25 mm, Merck) plates were used.

\subsection{Plant Material}

Shoots of Chinese chive were collected at the Naju, Jeolla Province, South Korea in July 2018. A voucher specimen (AT201807) is deposited at the Herbarium of College of Pharmacy, Yonsei Institute of Pharmaceutical Sciences, Yonsei University, Incheon, Korea.

\subsection{UPLC-QTOF-MS Analysis}

Methanol extracts of Chinese chive's shoots $(1 \mathrm{mg} / \mathrm{mL}, 10 \mu \mathrm{L})$ was analyzed by the instrument consisted of a Waters ACQUITY UPLC system (Waters Corp., Milford, MA, USA) connecting to a quadrupole time of flight mass spectrometer (Xevo G2-XS QTOF, Waters Corp.). YMC-Triart C18 column $(2.0 \times 150 \mathrm{~mm}, 1.9 \mu \mathrm{m}$; YMC KOREA Co., Seongnam, Korea) was used for compound separation at the condition of $25^{\circ} \mathrm{C}$. The mobile phases were water $(0.1 \%$ formic acid) and $\mathrm{ACN}(0.1 \%$ formic acid) with the following gradients: $5-95 \% \mathrm{ACN}$ (0-20 min), 95-100\% ACN (20-20.1 min), and 100\% ACN (20.1-25 $\min )$. The flow rate was $4 \mathrm{~mL} / \mathrm{min}$.

\subsection{Extraction and Isolation}

Shoots of Chinese chive $(4.0 \mathrm{~kg})$ were dried at $40{ }^{\circ} \mathrm{C}$ for one day, and the final dry mass was $450 \mathrm{~g}$. Dried shoots were extracted with $\mathrm{MeOH}$ under sonication at $30^{\circ} \mathrm{C}$ to yield an extract (83.7 g), which was then suspended in $\mathrm{H}_{2} \mathrm{O}$ and successively partitioned using hexane, $\mathrm{CHCl}_{3}$, and EtOAc to obtain EtOAc (AT-1C, $3.22 \mathrm{~g}$ ) and $\mathrm{H}_{2} \mathrm{O}$ (AT-1D, $71.5 \mathrm{~g}$ ) extracts after removal of the solvents in vacuo. The $\mathrm{H}_{2} \mathrm{O}$ fraction (AT-1D, $71.5 \mathrm{~g}$ ) was subjected to a Diaion HP-20 column and eluted with 25, 50, and $75 \% \mathrm{MeOH}$ to yield three sub-fractions, AT-W2A (3.8 g), AT-W2B (1.8 g), AT-W2C (1.1 g). The AT-W2B fraction was combined with AT-W2A fraction, and the integrated mass of AT-W2A $(5.6 \mathrm{~g})$ was applied to a silica gel column, and by eluting with $\mathrm{CHCl}_{3}: \mathrm{MeOH}: \mathrm{H}_{2} \mathrm{O}(2: 1: 0.2, v / v / v)$ gave six sub-fractions, AT-W3A (0.2 g), AT-W3B (0.3 g), AT-W3C (0.4 g), AT-W3D (0.3 g), AT-W3E $(0.3 \mathrm{~g})$, and AT-W3F $(0.5 \mathrm{~g})$. The AT-W3A fraction was subjected to HPLC system, eluted with $\mathrm{MeCN}: \mathrm{H}_{2} \mathrm{O}(7: 93)$ to yield 3 (13.8 mg) and 4 (14.8 mg). Subsequently, AT-W3B and AT-W3C fractions were eluted with the same HPLC conditions and solvent composition as above to yield $5(3.5 \mathrm{mg})$ and $\mathbf{6}(17.5 \mathrm{mg})$ respectively. Compound $\mathbf{7}(3.3 \mathrm{mg})$ and $8(8.4 \mathrm{mg})$ were obtained from fraction AT-W3E, also eluted with $\mathrm{MeCN}: \mathrm{H}_{2} \mathrm{O}(7: 93)$. AT-W2C (1.1 g) was applied to a silica gel column, and by eluting with $\mathrm{CHCl}_{3}: \mathrm{MeOH}: \mathrm{H}_{2} \mathrm{O}(2: 1: 0.2, v / v / v)$ gave four smaller fractions, AT-W4A (0.2 g), AT-W4B (0.1 g), AT-W4C (0.1 g), AT-W4D (0.2 g). The AT-W4B fraction was subjected to HPLC as above, eluted with $\mathrm{MeCN}: \mathrm{H}_{2} \mathrm{O}(25: 75)$ to yield $\mathbf{1}(10.0 \mathrm{mg})$, whereas the AT-W4C fraction gave $\mathbf{2}(15.1 \mathrm{mg})$ when eluted with the same solvent composition. 


\subsection{Kaempferol-3-O-(6"-feruloyl)-sophoroside (1)}

Yellow amorphous powder; $\mathrm{C}_{37} \mathrm{H}_{38} \mathrm{O}_{19}$, HR-ESI-MS m/z: $809.1889[\mathrm{M}+\mathrm{Na}]^{+}$(calcd for $\mathrm{C}_{37} \mathrm{H}_{38} \mathrm{O}_{19} \mathrm{Na}$, 809.1900); for ${ }^{1} \mathrm{H}\left(\mathrm{CD}_{3} \mathrm{OD}, 400 \mathrm{MHz}\right)$ and ${ }^{13} \mathrm{C}$ NMR $\left(\mathrm{CD}_{3} \mathrm{OD}, 100 \mathrm{MHz}\right)$ spectroscopic data; see Table 1.

\subsection{Acid Hydrolysis of $\mathbf{1}$}

Compound $1(2 \mathrm{mg}$ ) was dissolved in $1 \mathrm{~N} \mathrm{HCl}$ (dioxane- $\mathrm{H} 2 \mathrm{O}, 1: 1,1 \mathrm{~mL}$ ) and heated to $80^{\circ} \mathrm{C}$ in a water bath for $3 \mathrm{~h}$. The acidic solution was neutralized with silver carbonate, and the solvent was thoroughly driven out under $\mathrm{N}_{2}$ gas overnight. After extraction with $\mathrm{CHCl}_{3}$, the aqueous layer was concentrated to dryness using $\mathrm{N}_{2}$ gas. The residue was dissolved in $0.1 \mathrm{~mL}$ of dry pyridine, followed by addition of L-cysteine methyl ester hydrochloride in pyridine $(0.06 \mathrm{M}, 0.1 \mathrm{~mL})$. The reaction mixture was heated at $60^{\circ} \mathrm{C}$ for $2 \mathrm{~h}$. Trimethylsilylimidazole solution $(0.1 \mathrm{~mL})$ was then added, followed by heating at $60^{\circ} \mathrm{C}$ for $1.5 \mathrm{~h}$. The dried product was partitioned with $\mathrm{n}$-hexane and water $(0.1 \mathrm{~mL}$ each), and the organic layer was analyzed by gas chromatography (GC): column SPB-1 $(0.25 \mathrm{~mm} \times 30 \mathrm{~m})$, detector FID, column temp $210{ }^{\circ} \mathrm{C}$, injector temp $270{ }^{\circ} \mathrm{C}$, detector temp $300{ }^{\circ} \mathrm{C}$, carrier gas He $(30 \mathrm{~mL} / \mathrm{min})$. Under these conditions, standard sugars gave peaks at $t_{R}(\mathrm{~min}) 8.55$ and 9.25 for $\mathrm{D}$ - and L-glucose, respectively. Peaks at $t_{R}(\mathrm{~min}) 8.55$ of D-glucose for 1 were observed.

\subsection{Materials for Skeletal Muscle Cell Proliferation Activity}

$\mathrm{C} 2 \mathrm{C} 12$, a mouse myoblasts cell line, was purchased from the American Type Culture Collection (ATCC, Manassas, VA, USA). Dulbecco's Modified Eagle Medium (DMEM), fetal bovine serum (FBS), horse serum (HS), penicillin-streptomycin, trypsin-EDTA, and Dulbecco's Phosphate Buffered Saline (DPBS) were acquired from Gibco-BRL (Burlington, Ont, Canada). All the other chemicals used were of analytical grade.

\subsection{Cell Culture and Differentiation}

C2C12 cells were maintained in DMEM supplemented with 10\% heat-inactivated FBS, streptomycin $(100 \mathrm{mg} / \mathrm{mL})$, and penicillin $(100 \mathrm{unit} / \mathrm{mL})$ at $37{ }^{\circ} \mathrm{C}$ under $5 \% \mathrm{CO}_{2}$ humidified incubator. To induce differentiation, $80 \%$ confluent cultures were switched to DMEM containing $2 \% \mathrm{HS}$ for six days with medium changes every other day.

\subsection{Skeletal Muscle Cell Proliferation Activity}

First, cytotoxicity was evaluated before measuring the cell proliferation activity of eight compounds isolated from Chinese chive. The cytotoxic assessment was performed according to the method described in Muthuramalingam et al. (2019) [36] with a slight modification. Briefly, after $24 \mathrm{~h}$ of cell seeding with $1 \times 10^{5}$ cells per well ( 96 well plate), isolated compounds were treated for $24 \mathrm{~h}$. Afterward, cytotoxic assessment was performed using MTT assay. The formazan crystals were dissolved in DMSO, and the absorbance was measured using an ELISA plate reader at $540 \mathrm{~nm}$ (BioTek Instruments, Inc., Winooski, VT, USA). The optical density of the formazan generated in non-treated control cells was considered to represent $100 \%$ viability. To assess the skeletal muscle cell proliferation activity, activities were determined using BrdU assay (Millipore, Billerica, MA, USA) according to the method used in Kim et al. (2019) [37]. Briefly, after $48 \mathrm{~h}$ of the initial cell seeding with $5 \times 10^{4}$ cells per well (96 well plate), the growth medium (DMEM containing $10 \%$ FBS) was replaced with differentiation medium (DMEM containing $2 \% \mathrm{HS}$ ) and treated phytochemicals every other day during differentiation period. Finally, six days after the differentiation induction, cell proliferation activity was measured using BrdU assay.

\subsection{Western Blot Analysis}

Western blot analysis was carried out to observe the effect of eight compounds on skeletal muscle differentiation through the analysis of the expression of proteins involved in the myogenesis signaling cascade using the protocol described by Muthuramalingam and Kim et al. (2019). The eight compounds were treated with differentiation media (DMEM 
containing $2 \%$ HS) every each other during the cell differentiation period. Afterward, cytoplasmic and nuclear proteins were collected, and cellular proteins were separated by $12 \%$ sodium dodecyl sulfated (SDS)-polyacrylamide gel electrophoresis (PAGE) and transferred to nitrocellulose membranes. The membranes were blocked with $5 \%$ skim milk (in Tris buffered saline containing $0.2 \%$ Tween-20) and incubated overnight at $4{ }^{\circ} \mathrm{C}$ with relevant primary antibodies (1:1000 dilution in 5\% skim milk) to identify proteins that inhibit or activate skeletal muscle cell synthesis. Following the HRP-conjugated secondary antibodies (1:3000 dilution in 5\% skim milk), they were added to the membranes and were incubated for $90 \mathrm{~min}$ at room temperature. Finally, the bands were developed using chemiluminescent substrate and photographed using a FUSION FX Spectra program equipped with eVo-6 camera (Vilber Lourmat, Marne-La-Vallée, France). The band intensities were quantified using the Image J program.

\section{Conclusions}

In this study, we investigated the muscle growth activity of newly discovered flavonoid and amino acids from Chinese chive. Our results demonstrated that two active compounds interacted with muscle-related signaling pathways and induced skeletal muscle growth and differentiation. In particular, compound 1 promoted PI3K/Akt/mTOR pathways, which are positive signaling pathways, while simultaneously decreasing Smad pathways, the negative regulator of skeletal muscle growth. Compound 7 also activated PI3K/Akt/mTOR pathways. Taken together, we suggest that major constituents of Chinese chive, identified as flavonoids and amino acids, might be used as functional food candidates for aiding muscle growth and differentiation.

Supplementary Materials: The following are available online at https:/ /www.mdpi.com/1422-0067/ 22/5/2296/s1, Figure S1. The networking analysis of Chinese chive by NAP. Figure S2. HR-ESI-MS of compound 1. Figure S3. ${ }^{1} \mathrm{H}-\mathrm{NMR}$ spectrum of compound $1\left(400 \mathrm{MHz}\right.$, methanol- $\left.d_{4}\right)$. Figure S4. ${ }^{13} \mathrm{C}-\mathrm{NMR}$ spectrum of compound $\mathbf{1}\left(100 \mathrm{MHz}\right.$, methanol- $\left.d_{4}\right)$. Figure S5. HSQC spectrum of compound 1 (methanol- $\left.d_{4}\right)$. Figure S6. HMBC spectrum of compound 1 (methanol- $\left.d_{4}\right)$. Figure S7. Skeletal muscle cell differentiation activities of compounds 1 and 7 from Chinese chive on C2C12 cells.

Author Contributions: Conceptualization, M.O., S.-Y.K., and S.H.K.; formal analysis, M.O. and S.Y.K.; investigation, M.O. and S.-Y.K.; methodology, S.P. and K.-N.K.; resources, K.-N.K.; supervision, K.-N.K. and S.H.K.; writing-original draft, M.O. and S.-Y.K.; writing-review and editing, S.P. and S.H.K. All authors have read and agreed to the published version of the manuscript.

Funding: This research was supported by the National Research Foundation of Korea (NRF) grant [2020R1A2C101263211] and [2018R1A6A1A03023718].

Institutional Review Board Statement: Not applicable.

Informed Consent Statement: Not applicable.

Data Availability Statement: The data presented in this study are available on request from the corresponding author.

Conflicts of Interest: The authors declare no conflict of interest.

\section{References}

1. McCormick, R.; Vasilaki, A. Age-related changes in skeletal muscle: Changes to life-style as a therapy. Biogerontology 2018, 19, 519-536. [CrossRef] [PubMed]

2. Kim, C.H.; Shin, J.-H.; Hwang, S.J.; Choi, Y.H.; Kim, D.-S.; Kim, C.M. Schisandrae fructus enhances myogenic differentiation and inhibits atrophy through protein synthesis in human myotubes. Int. J. Nanomed. 2016, 11, 2407. [CrossRef] [PubMed]

3. Zhong, Y.D.C.D. The Dictionary of Chinese Drugs; Shanghai Science and Technological Publisher: Shanghai, China, $1985 ;$ p. 2383.

4. Tang, X.; Olatunji, O.J.; Zhou, Y.; Hou, X. Allium tuberosum: Antidiabetic and hepatoprotective activities. Food Res. Int. 2017, 102, 681-689. [CrossRef] [PubMed]

5. Choudhary, R. Benificial effect of Allium sativum and Allium tuberosum on experimental hyperlipidemia and atherosclerosis. Pak. J. Physiol. 2008, 4, 7-10. 
6. $\quad$ Park, S.-Y.; Kim, J.-Y.; Park, K.-W.; Kang, K.-S.; Park, K.-H.; Seo, K.-I. Effects of thiosulfinates isolated from Allium tuberosum L. on the growth of human cancer cells. J. Korean Soc. Food Sci. Nutr. 2009, 38, 1003-1007. [CrossRef]

7. Gautam, S.; Pal, S.; Maurya, R.; Srivastava, A.K. Ethanolic extract of Allium cepa stimulates glucose transporter typ 4-mediated glucose uptake by the activation of insulin signaling. Planta Med. 2015, 81, 208-214. [CrossRef]

8. Yang, J. Enhanced skeletal muscle for effective glucose homeostasis. Prog. Mol. Biol. Ttransl. Sci. 2014, 121, 133-163.

9. Xie, W.; Zhang, Y.; Wang, N.; Zhou, H.; Du, L.; Ma, X.; Shi, X.; Cai, G. Novel effects of macrostemonoside A, a compound from Allium macrostemon Bung, on hyperglycemia, hyperlipidemia, and visceral obesity in high-fat diet-fed C57BL/6 mice. Eur. J. Pharmacol. 2008, 599, 159-165. [CrossRef]

10. Kalhotra, P.; Chittepu, V.C.; Osorio-Revilla, G.; Gallardo-Velazquez, T. Phytochemicals in garlic extract inhibit therapeutic enzyme DPP-4 and induce skeletal muscle cell proliferation: A possible mechanism of action to benefit the treatment of diabetes mellitus. Biomolecules 2020, 10, 305. [CrossRef]

11. Da Silva, R.R.; Wang, M.; Nothias, L.-F.; van der Hooft, J.J.; Caraballo-Rodríguez, A.M.; Fox, E.; Balunas, M.J.; Klassen, J.L.; Lopes, N.P.; Dorrestein, P.C. Propagating annotations of molecular networks using in silico fragmentation. PLoS Comput. Biol. 2018, 14, e1006089. [CrossRef]

12. Aron, A.T.; Gentry, E.C.; McPhail, K.L.; Nothias, L.-F.; Nothias-Esposito, M.; Bouslimani, A.; Petras, D.; Gauglitz, J.M.; Sikora, N.; Vargas, F. Reproducible molecular networking of untargeted mass spectrometry data using GNPS. Nat. Protoc. 2020, 15, 1954-1991. [CrossRef] [PubMed]

13. Feunang, Y.D.; Eisner, R.; Knox, C.; Chepelev, L.; Hastings, J.; Owen, G.; Fahy, E.; Steinbeck, C.; Subramanian, S.; Bolton, E. ClassyFire: Automated chemical classification with a comprehensive, computable taxonomy. J. Cheminform. 2016, 8, 61. [CrossRef]

14. Markham, K.; Ternai, B.; Stanley, R.; Geiger, H.; Mabry, T. Carbon-13 NMR studies of flavonoids-III: Naturally occurring flavonoid glycosides and their acylated derivatives. Tetrahedron 1978, 34, 1389-1397. [CrossRef]

15. Xiao, Y.; Wang, Y.L.; Gao, S.X.; Sun, C.; Zhou, Z.Y. Chemical composition of Hydrilla verticillata (L. f.) royle in Taihu lake. Chin. J. Chem. 2007, 25, 661-665. [CrossRef]

16. Ciuffreda, P.; Casati, S.; Manzocchi, A. Complete ${ }^{1} \mathrm{H}$ and ${ }^{13} \mathrm{C}$ NMR spectral assignment of $\alpha$-and $\beta$-adenosine, $2^{\prime}$-deoxyadenosine and their acetate derivatives. Magn. Reson. Chem. 2007, 45, 781-784. [CrossRef]

17. Mantsch, H.; Smith, I.C. Fourier-transformed ${ }^{13} \mathrm{C}$ NMR spectra of polyuridylic acid, uridine, and related nucleotides-the use of ${ }^{31} \mathrm{POC}^{13} \mathrm{C}$ couplings for conformational analysis. Biochem. Bioph. Res. Commun. 1972, 46, 808-815. [CrossRef]

18. Flores-Sanchez, I.J.; Peč, J.; Fei, J.; Choi, Y.H.; Dušek, J.; Verpoorte, R. Elicitation studies in cell suspension cultures of Cannabis sativa L. J. Biotechnol. 2009, 143, 157-168. [CrossRef] [PubMed]

19. Tatsuzawa, F.; Aiba, Y.; Morino, T.; Saito, N.; Shinoda, K.; Kato, K.; Toki, K.; Honda, T. Copigmentation with acylated anthocyanin and kaempferol glycosides in violet and purple flower cultivars of Aubrieta $\times$ cultorum (Brassicaceae). J. Jpn. Soc. Hortic. Sci. 2012, 81, 275-284. [CrossRef]

20. Kamel, M.S.; Mohamed, K.M.; Hassanean, H.A.; Ohtani, K.; Kasai, R.; Yamasaki, K. Acylated flavonoid glycosides from Bassia muricata. Phytochemistry 2001, 57, 1259-1262. [CrossRef]

21. Tureckova, J.; Wilson, E.M.; Cappalonga, J.L.; Rotwein, P. Insulin-like growth factor-mediated muscle differentiation collaboration between phosphatidylinositol 3-kinase-Akt-signaling pathways and myogenin. J. Biol. Chem. 2001, 276, 39264-39270. [CrossRef]

22. Jacquemin, V.; Butler-Browne, G.S.; Furling, D.; Mouly, V. IL-13 mediates the recruitment of reserve cells for fusion during IGF-1-induced hypertrophy of human myotubes. J. Cell Sci. 2007, 120, 670-681. [CrossRef]

23. Kim, J.; Park, M.Y.; Kim, H.K.; Park, Y.; Whang, K.-Y. Cortisone and dexamethasone inhibit myogenesis by modulating the AKT/mTOR signaling pathway in C2C12. Biosci. Biotech. Bioch. 2016, 80, 2093-2099. [CrossRef]

24. Elkina, Y.; von Haehling, S.; Anker, S.D.; Springer, J. The role of myostatin in muscle wasting: An overview. J. Cachexia Sarcopenia Muscle 2011, 2, 143. [CrossRef] [PubMed]

25. Zhang, Z.-K.; Jie, L.; Jin, L.; Baosheng, G.; Leung, A.; Zhang, G.; Zhang, B.-T. Icaritin requires Phosphatidylinositol 3 kinase (PI3K)/Akt signaling to counteract skeletal muscle atrophy following mechanical unloading. Sci. Rep. 2016, 6, 20300. [CrossRef] [PubMed]

26. Sung, B.; Hwang, S.Y.; Kim, M.J.; Kim, M.; Jeong, J.W.; Kim, C.M.; Chung, H.Y.; Kim, N.D. Loquat leaf extract enhances myogenic differentiation, improves muscle function and attenuates muscle loss in aged rats. Int. J. Mol. Med. 2015, 36, 792-800. [CrossRef]

27. Zhao, B.; Xiong, Y.; Zhang, Y.; Jia, L.; Zhang, W.; Xu, X. Rutin promotes osteogenic differentiation of periodontal ligament stem cells through the GPR30-mediated PI3K/AKT/mTOR signaling pathway. Exp. Biol. Med. 2020, 245, 552-561. [CrossRef]

28. Ali, M.Y.; Zaib, S.; Rahman, M.M.; Jannat, S.; Iqbal, J.; Park, S.K.; Chang, M.S. Poncirin, an orally active flavonoid exerts antidiabetic complications and improves glucose uptake activating PI3K/Akt signaling pathway in insulin resistant C2C12 cells with anti-glycation capacities. Bioorg. Chem. 2020, 102, 104061.

29. Tato, I.; Bartrons, R.; Ventura, F.; Rosa, J.L. Amino acids activate mammalian target of rapamycin complex 2 (mTORC2) via PI3K/Akt signaling. J. Biol. Chem. 2011, 286, 6128-6142. [CrossRef] [PubMed]

30. Saha, A.; Connelly, S.; Jiang, J.; Zhuang, S.; Amador, D.T.; Phan, T.; Pilz, R.B.; Boss, G.R. Akt phosphorylation and regulation of transketolase is a nodal point for amino acid control of purine synthesis. Mol. Cell 2014, 55, 264-276. [CrossRef] [PubMed]

31. Yoon, M.-S.; Chen, J. Distinct amino acid-sensing mTOR pathways regulate skeletal myogenesis. Mol. Biol. Cell 2013, 24, 3754-3763. [CrossRef] [PubMed] 
32. Liu, D.; Black, B.L.; Derynck, R. TGF- $\beta$ inhibits muscle differentiation through functional repression of myogenic transcription factors by Smad3. Gene. Dev. 2001, 15, 2950-2966. [CrossRef] [PubMed]

33. Wu, Y.-T.; Chen, L.; Tan, Z.-B.; Fan, H.-J.; Xie, L.-P.; Zhang, W.-T.; Chen, H.-M.; Li, J.; Liu, B.; Zhou, Y.-C. Luteolin inhibits vascular smooth muscle cell proliferation and migration by inhibiting TGFBR1 signaling. Front. Pharmacol. 2018, 9, 1059. [CrossRef] [PubMed]

34. Gao, F.; He, X.; Liang, S.; Liu, S.; Liu, H.; He, Q.; Chen, L.; Jiang, H.; Zhang, Y. Quercetin ameliorates podocyte injury via inhibition of oxidative stress and the TGF- $\beta 1 /$ Smad pathway in DN rats. RSC Adv. 2018, 8, 35413-35421. [CrossRef]

35. Zhang, Y.; Shan, S.; Wang, J.; Cheng, X.; Yi, B.; Zhou, J.; Li, Q. Galangin inhibits hypertrophic scar formation via ALK5/Smad2/3 signaling pathway. Mol. Cell. Biochem. 2016, 413, 109-118. [CrossRef] [PubMed]

36. Muthuramalingam, K.; Kim, S.-Y.; Kim, Y.; Kim, H.-S.; Jeon, Y.-J.; Cho, M. Bigbelly seahorse (Hippocampus abdominalis)-derived peptides enhance skeletal muscle differentiation and endurance performance via activated P38MAPK/AKT signalling pathway: An in vitro and in vivo analysis. J. Funct. Foods 2019, 52, 147-155. [CrossRef]

37. Kim, S.-Y.; Kim, H.-S.; Cho, M.; Jeon, Y.-J. Enzymatic Hydrolysates of Hippocampus abdominalis Regulates the Skeletal Muscle Growth in C2C12 Cells and Zebrafish Model. J. Aquat. Food Prod. Technol. 2019, 28, 264-274. [CrossRef] 